\title{
Super lekka platforma kontenerowa o zmiennej długości
}

\begin{abstract}
$W$ artykule zaprezentowano nowatorskie rozwiqzanie platformy do przewozu kontenerów. Platforma charakteryzuje się mała masq własnq oraz posiada właściwość zmiany dtugości, która może być dostosowana do dlugości kontenera, zwłaszcza 40 i 30 stopowego. Podano krótki opis podstawowych zespołów oraz przedstawiono zalety prezentowanego rozwiazania.
\end{abstract}

\section{Wprowadzenie}

Obecnie wykorzystywany powszechnie w transporcie intermodalnym park środków transportu jest bardzo ograniczony i sprowadza się do klasycznej platformy kontenerowej, wagonu kieszeniowego lub koszowego i niskopodwoziowej platformy. Wagony te mają określone wady eksploatacyjne, które stwarzają pewne ograniczenia $\mathrm{w}$ ich optymalnym wykorzystaniu. Platformy kontenerowe nie zawsze mają zajętą cała powierzchnię ładunkową. Stopień zajętości powierzchni zależy od wielkości i ilości przewożonych kontenerów. W przypadku przewozu średnich i małych kontenerów powstają pomiędzy nimi puste przestrzenie. Niewypełnione przestrzenie między kontenerami oraz przestrzenie, które zajmują zderzaki między sassiednimi platformami, decydują o liczbie transportowanych kontenerów przy zadanej długości pociagu. Wady te można w dużej mierze wyeliminować, stosując nowatorskie rozwiązanie w postaci platformy kontenerowej o zmiennej długości.
Istotą rozwiązania jest konstrukcja dwuosiowego wagonu z dzieloną belką grzbietową, złożoną $\mathrm{z}$ belki podłużnej zewnętrznej i belki podłużnej wewnętrznej, przy czym belka wewnętrzna jest wsunięta w belkę zewnętrzną na określoną głębokość, a głębokość wsunięcia belek może być ustalona w kilku (minimum dwóch) położeniach przy pomocy klina umieszczonego w otworach belek.

\section{Pociąg kontenerowy}

$\mathrm{Na}$ rysunku 1 zaprezentowano krótko spięty pociag kontenerowy złożony z platform o zmiennej długości, w skład którego wchodzą: platforma końcowa lewa (1), platforma środkowa (2) i platforma końcowa prawa (3). Na platformie końcowej lewej pokazano przykładowo zamocowany kontener $40^{\prime}$ (4), na platformie środkowej kontener 30' (5) i możliwość zamocowania kontenera 20' (6), a na platformie końcowej prawej kontener 20' (6).

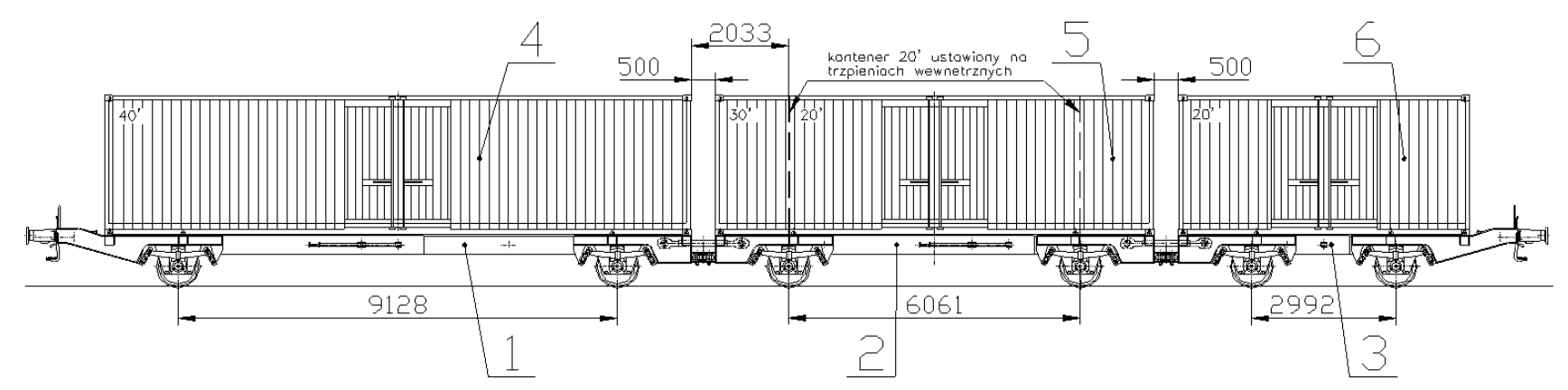

Rys. 1. Krótko spięty pociąg złożony z platform kontenerowych o zmiennej długości

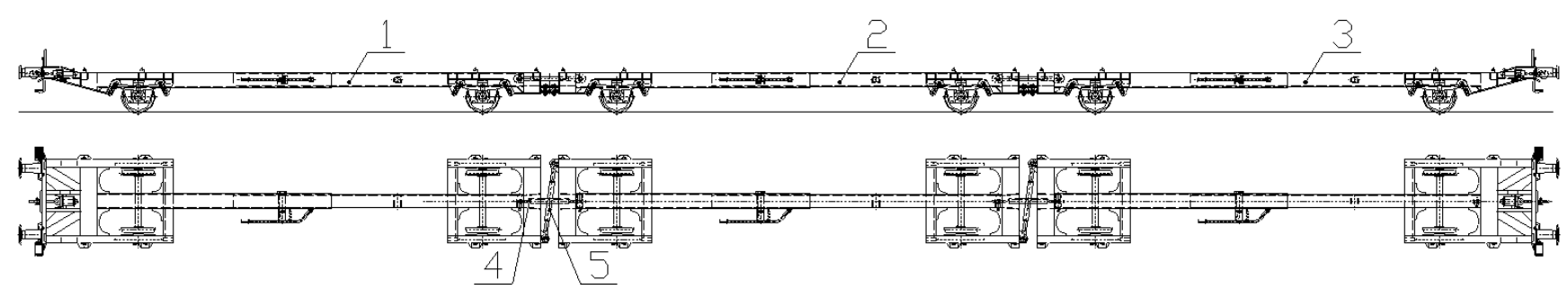

Rys. 2. Zestaw platform kontenerowych związanych połączeniem międzywagonowym 
Platformę końcową lewą przedstawiono w stanie maksymalnie wydłużonym do długości $9128 \mathrm{~mm}$ między zestawami kołowymi, pozwalającej zamocować kontener 40', platformę środkową pokazano $\mathrm{w}$ stanie skróconym do rozstawu zestawów kołowych wynoszącym $6061 \mathrm{~mm}$, umożliwiającym postawienie kontenerów 30' i końcową prawą w stanie maksymalnie skróconym do rozstawu zestawów kołowych wynoszącym $2992 \mathrm{~mm}$, umożliwiającym postawienie kontenerów 20'. Dla kontenerów 40' i 30' można uzyskać małą odległość między nimi wynoszącą $\sim 500 \mathrm{~mm}$. Natomiast dla kontenerów 20’ zmniejszenie odległości zestawów kołowych wymaga zastosowania specjalnego $\mathrm{np}$. teleskopowego połączenia belek grzbietowych oraz zastosowania dwóch urządzeń ryglujących, co komplikuje konstrukcję. Wynika $\mathrm{z}$ tego, że proponowana koncepcja rozwiązania konstrukcyjnego platformy o zmiennej długości jest najkorzystniejsza do transportu kontenerów 40' i 30'.

$\mathrm{Na}$ rysunku 2 przedstawiono krótko spięte platformy kontenerowe zestawione $\mathrm{w}$ pociagu złożonym $z$ trzech platform:

- platformy końcowej lewej (1),

- platformy środkowej (2),

- platformy końcowej prawej (3).

Platformy: końcową lewą i końcową prawą połączono z platformą środkową za pomocą połączenia międzywagonowego $\mathrm{w}$ postaci sztywnego draga (4), zamocowanego przegubowo do czołownic sąsiednich platform oraz poprzecznego amortyzatora (5), którego końce umocowano przegubowo we wspornikach zabudowanych po przeciwnych stronach czołownic platformy środkowej i platform końcowych.
Zaprezentowaną ideę rozwiązania konstrukcyjnego platformy o zmiennej długości można również zastosować do platformy wyposażonej w tradycyjne urządzenia pociągowo-zderzne tj. $\mathrm{w}$ zderzaki $\mathrm{i}$ aparat pociagowy zamiast sztywnego draga. Przykład takiego rozwiązania dla kontenera 40 ' pokazano na rysunku 3.

Możliwe jest również zbudowanie zestawu kilku krótko spiętych platform, zaopatrzonego we własne jednostki napędowe, sprzężone urządzeniem międzywagonowym z platformami końcowymi zestawu platform. Jednostki napędowe wyposażone w silniki spalinowe stosowane w ciagnikach siodłowych zapewniają niezbedna moc do transportu kilku kontenerów z prędkością do $100 \mathrm{~km} / \mathrm{h}$. W ten sposób można zbudować pociag kontenerowy typu CARGOSPRINTER. Przykład takiego rozwiązania pokazano na rysunku 4.

Przedstawiony sposób połączenia międzywagonowego jest innowacyjnym, autorskim rozwiązaniem i został zgłoszony do ochrony patentowej.

\section{Platforma końcowa}

Platforma końcowa pokazana na rysunku 5, składa się z ramy zewnętrznej (1) z belką podłużną zewnętrzną (2), ramy wewnętrznej (3) z belką podłużną wewnętrzną (4), zestawów kołowych z usprężynowaniem i prowadzeniem (5) i mechanizmu ryglującego (6).

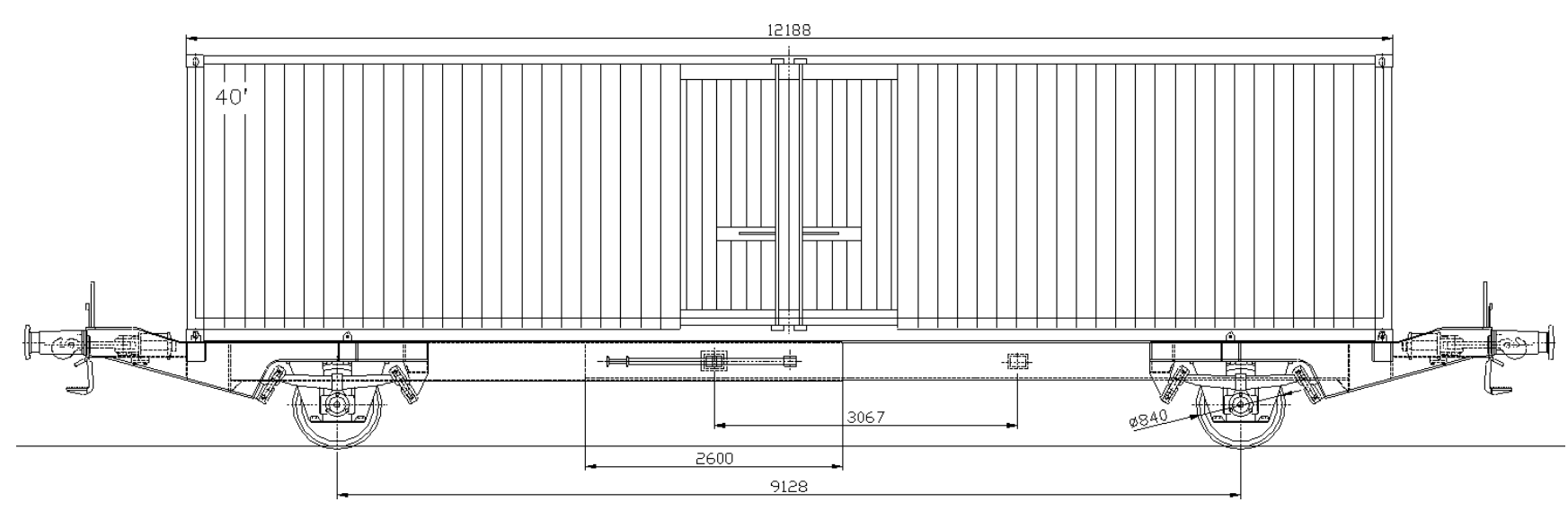

Rys. 3. Platforma kontenerowa o regulowanej długości wyposażona w zderzaki i aparat pociagowy

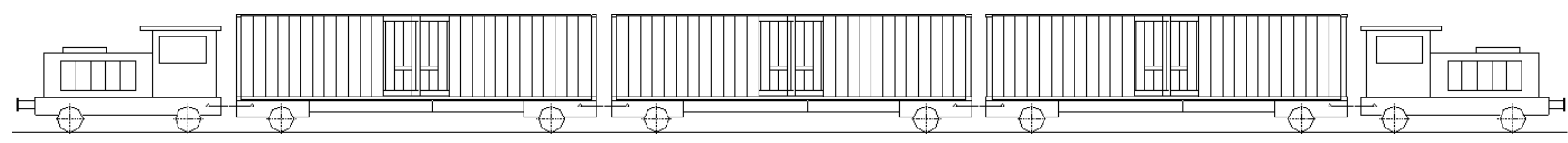

Rys. 4. Zestaw kontenerowy typu CARGO-SPRINTER 


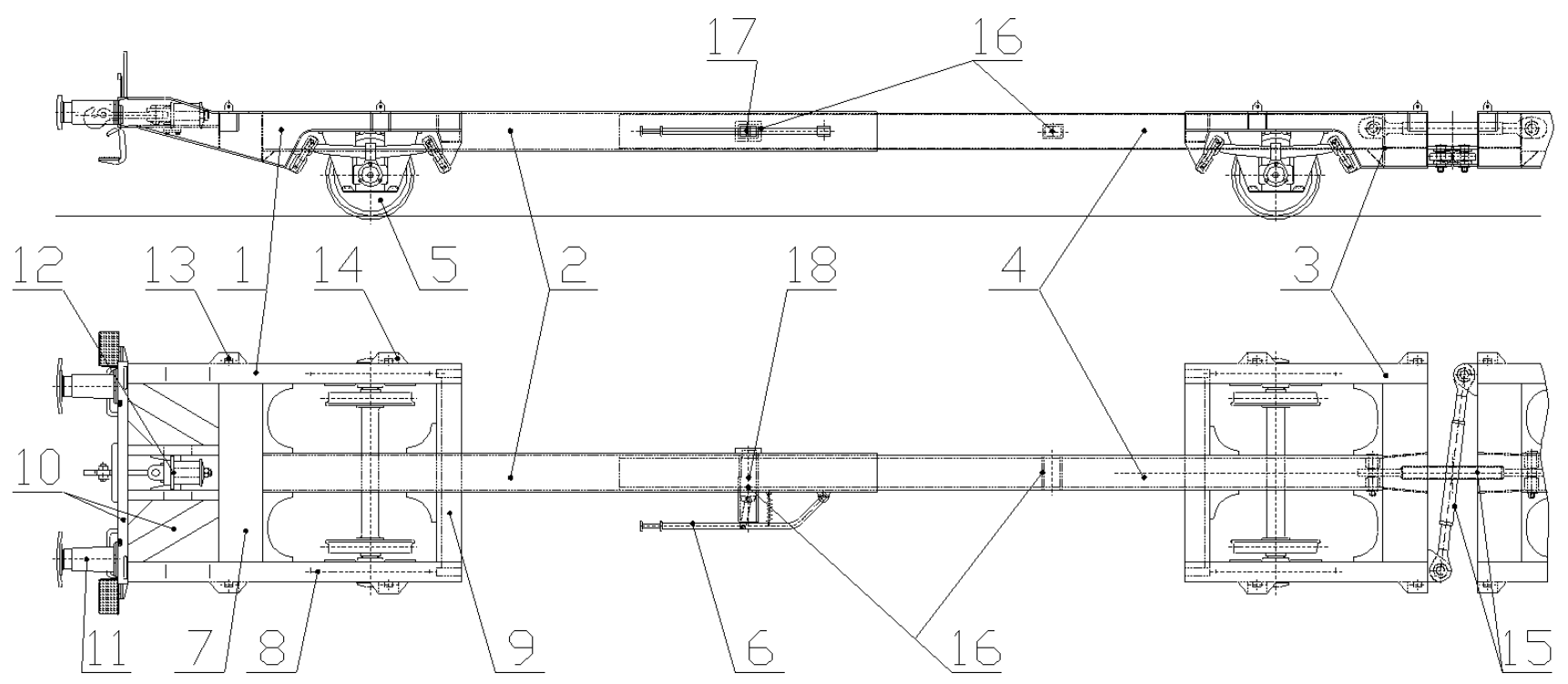

Rys. 5. Platforma końcowa

Rama (1) złożona jest z belek o konstrukcji spawanej, w skład której wchodzą: czołownica (7), podłużnice (8) oraz belka poprzeczna (9). Z czołownicą związano konstrukcję nośną (10), w której umieszczono elementy pociagowo - zderzne, to jest zderzaki (11) oraz aparat pociagowy (12). Na podłużnicach zamocowano trzpienie kontenerowe zewnętrzne (13) i wewnętrzne (14). Ramę (3) zbudowano podobnie jak ramę (1), ale bez konstrukcji (10), a czołownicę ramy przystosowano do zabudowy urządzeń połączenia międzywagonowego (15). Belkę podłużną wewnętrzną (4) ramy wyposażono w dwa odpowiednio rozstawione otwory (16), a w belce podłużnej zewnętrznej (2) ramy (1) wykonano jeden otwór (17) o kształcie i wielkości zbliżonej do otworów (16) wykonanych w belce podłużnej wewnętrznej.

W pokrywające się otwory (16) i (17) zamontowano rygiel w postaci prostokątnego klina (18) lub walcowego sworznia, ustalający wzajemne położenie belki podłużnej zewnętrznej względem belki podłużnej wewnętrznej, co stanowi równocześnie ustalenie długości platformy.
$\mathrm{Na}$ rysunku 6 pokazano schematycznie przykładowe możliwe rozwiązanie mechanizmu ryglującego oraz wzajemne położenie belki podłużnej zewnętrznej względem belki podłużnej wewnętrznej.

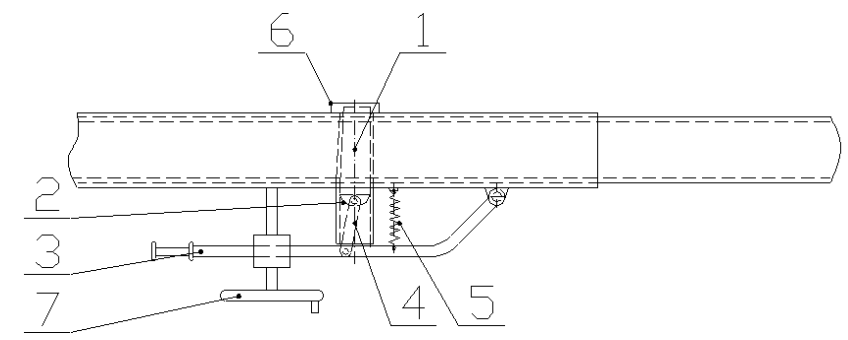

Rys. 6. Mechanizm ryglujący

Mechanizm ryglujący zbudowany jest z klina (1), prowadnicy (2), dźwigni (3), łącznika (4), sprężyny powrotnej (5), ogranicznika skoku klina (6) i mechanizmu wspomagającego otwieranie klina(7). Rozwiązanie szczegółowe mechanizmu ryglującego może zawierać dodatkowe urządzenia np. automatyzujące proces ryglowania belek.

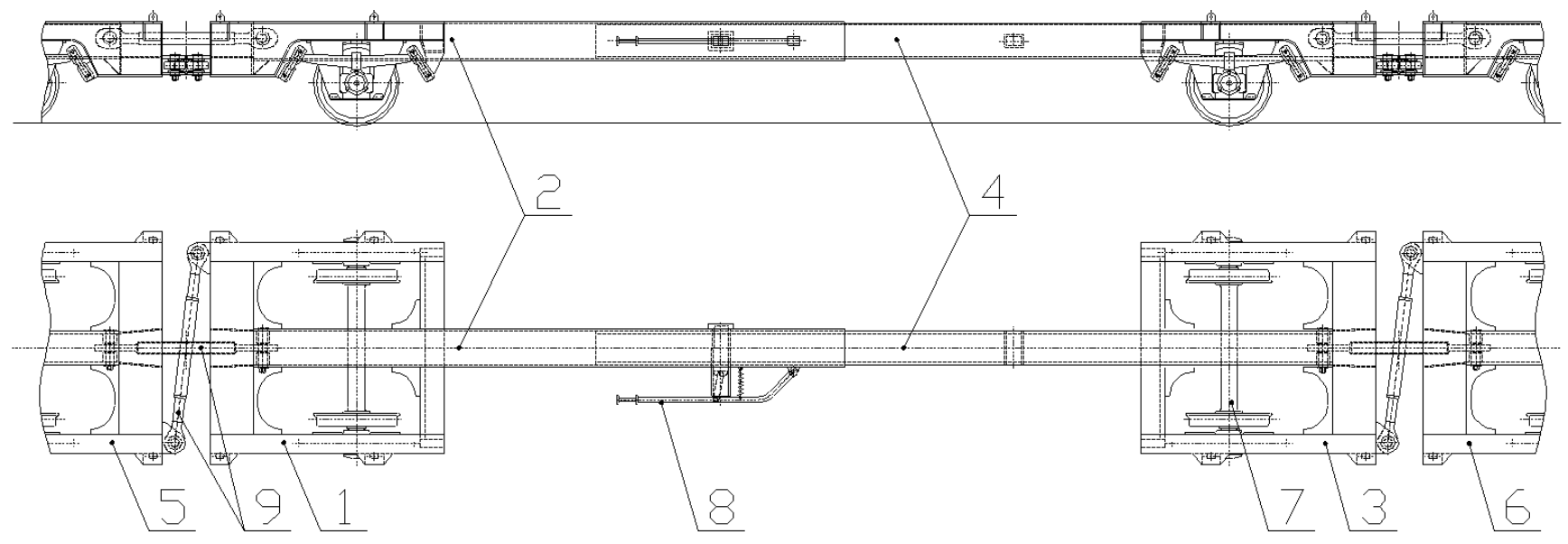

Rys. 7. Platforma środkowa 


\section{Platforma środkowa} kową.

$\mathrm{Na}$ rysunku 7 przedstawiono platformę środ-

Platforma zbudowana jest $\mathrm{z}$ ramy (1) $\mathrm{z}$ centralną belką zewnętrzną (2) oraz ramy (3) z centralną belką wewnętrzną (4) i zestawów kołowych z maźnicami i ich prowadzeniem (7). Ramy (1 i 3) wyposażono $\mathrm{w}$ połączenie miedzywagonowe (9), łączące sąsiednie platformy (5 i 6). Platforma środkowa, podobnie jak platforma końcowa, jest wyposażona w urządzenie ryglujące $\mathbf{( 8 )}$.

Można regulować rozstaw osi zestawów kołowych wagonu i czopów mocujących kontenery tak, aby umieścić kontener 40' lub 30' na zewnętrznych czopach mocujących, a kontenery 20 ' na wewnętrznych czopach mocujacych. Przykład zamocowania kontenerów 40', 30' i 20' na platformach pokazano na rysunku 8 , gdzie na rysunku: 8 a przedstawiono kontenery $40^{\prime}$, na rysunku 8 b kontenery $30^{\prime}$, a na rysunku 8 c kontenery 20 '.
- mała odległość między kontenerami

- proste i tanie połączenie międzywagonowe

- $\quad$ siły ściskające i rozciaggające pociag przenosi belka centralna umieszczona $\mathrm{w}$ osi wzdłużnej pociagu

- małe momenty zginające konstrukcje platformy w płaszczyźnie pionowej z uwagi na oparcie kontenera na platformie blisko osi zestawów kołowych

- mała wrażliwość konstrukcji platformy na wichrowaty tor (duży stopień bezpieczeństwa ruchu na torach o złej jakości)

- większa ilość transportowanych kontenerów w porównaniu do tradycyjnego po-ciagu o tej samej długości

- możliwość adaptowania rozwiązania do wagonów - platform wyposażonych w zderzaki i aparat pociagowy

- możliwość zbudowania pociagu typu CARGO-SPRINTER.

$8 \mathrm{a}$

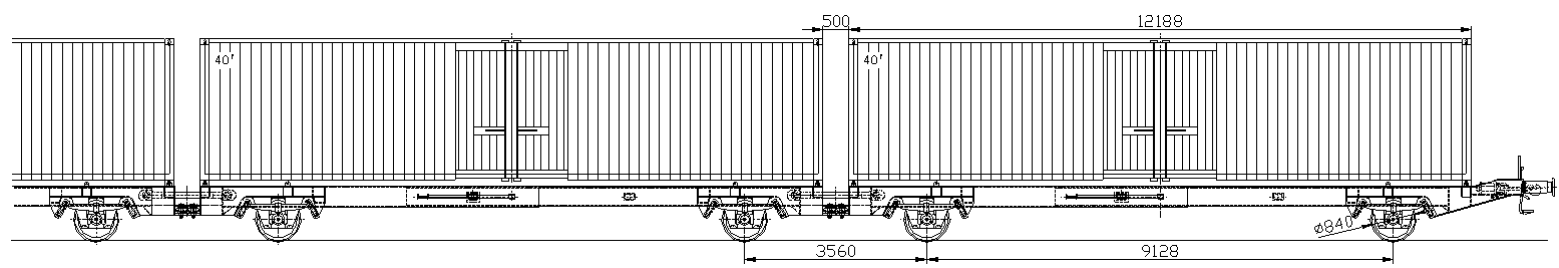

$8 \mathrm{~b}$

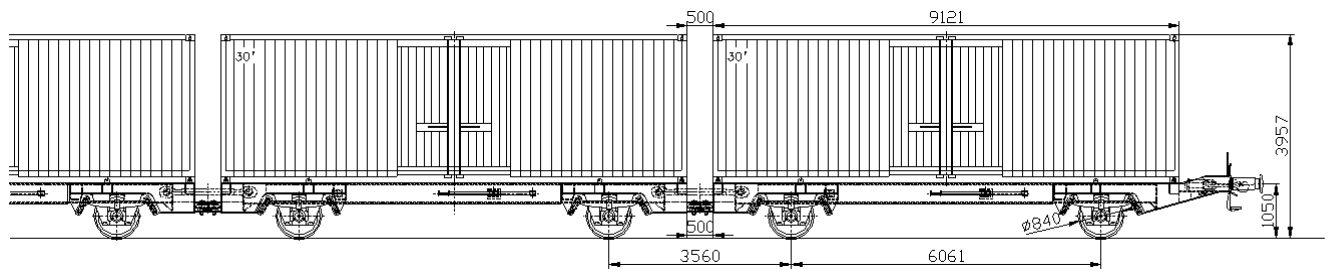

$8 \mathrm{c}$

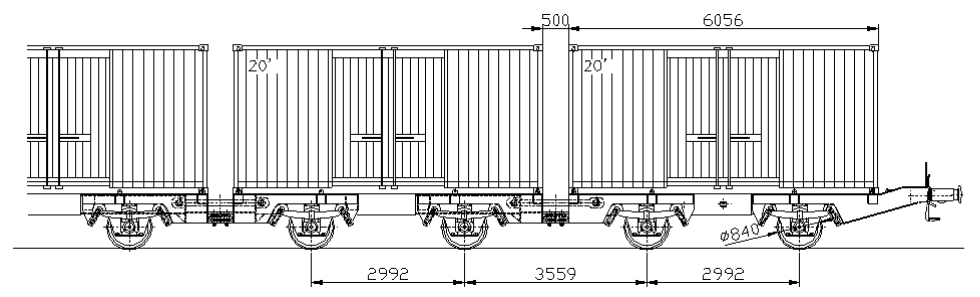

Rys. 8. Kontenery 40', 30' i 20 ' na platformach

\section{Zalety prezentowanego rozwiązania}

- prosta konstrukcja platformy - niskie koszty produkcji

- mała masa własna platformy (masa platformy nie może przekroczyć $11 \mathrm{t} \mathrm{z}$ uwagi na dopuszczalne naciski zestawu kołowego na tor); masa kontenera 40' i platformy wynosi 45t (34t + 11t)

- nacisk zestawu kołowego na tor wynosi 22,5 $\mathrm{kN}$
- zastosowana koncepcja krótko spiętego, wzdłużnie sztywnego pociagu pozwala wykorzystać „lżejsze” kryteria wytrzymałości konstrukcji na siły wzdłużne, np.: kryteria podane w karcie UIC 597 dotyczącej taboru bimodalnego (maksymalne siły wzdłużne \pm $850 \mathrm{kN}$, ściskanie pociagu w łuku S siłą 250 $\mathrm{kN})$. 


\section{Podsumowanie}

W opracowaniu przedstawiono koncepcję plat- Precedens takiego suwliwego połączenia ram występuformy, której rozwiązanie zostało zgłoszone do ochrony patentowej. W ramach projektu konstrukcyjnego należy poddać ocenie wytrzymałość konstrukcji oraz spełnienie warunków bezpieczeństwa ruchu. Oddzielnym problemem, który należy przeanalizować, to trwałość i niezawodność suwliwego połączenia belek grzbietowych platformy oraz ich wzajemnego ustalenia za pomocą połączenia klinowego lub sworzniowego. je w konstrukcji drogowych naczep kontenerowych i niskopodwoziowych. Nie można jednak w tym przypadku dokonać prostego porównania tych konstrukcji z uwagi na inny charakter obciążeń drogowych i kolejowych.

Z uwagi na podane zalety rozwiązania należy podjać prace nad projektem konstrukcyjnym i doprowadzić do budowy prototypów i przebadania platformy. 